\title{
MATERNAL TRAITS AND REPRODUCTIVE EFFORT IN NORTHERN ELEPHANT SEALS
}

\author{
Daniel E. Crocker, ${ }^{1}$ Jeannine D. Williams, Daniel P. Costa, and Burney J. Le Boeuf \\ Department of Biology, Institute of Marine Sciences, University of California, Santa Cruz, California 95064 USA
}

\begin{abstract}
The aim of this study was to determine the effects of maternal traits on reproductive expenditure and energy delivery to the offspring in a capital breeder, the northern elephant seal (Mirounga angustirostris). Changes in maternal and offspring energy reserves and milk-energy delivery were examined in relation to maternal parturition mass, body composition, and age in females and pups breeding at Año Nuevo State Reserve, California. Maternal body mass and composition had significant effects on maternal energy expenditure over lactation. Path analysis suggested no significant effects of maternal age on reproductive effort of parous females. The efficiency of milk production increased significantly with maternal age. Offspring metabolism was a relatively small component of maternal energy expenditure, with pups storing $84 \%$ of the energy obtained from milk. These effects are an important consequence of the phocid strategy for enabling terrestrial parturition despite marine feeding. This strategy has resulted in an abbreviated and highly efficient lactation system that is strongly impacted by body reserves, linking foraging success at sea with reproductive success on land. Maternal size, body composition, and age were important features of reproduction in northern elephant seals. These characteristics are rarely considered concurrently in life history studies.
\end{abstract}

Key words: Año Nuevo State Reserve, California; body composition; fasting; lactation energetics; maternal traits; metabolism; Mirounga angustirostris; northern elephant seal; physiological constraints; reproductive effort.

\section{INTRODUCTION}

Life history patterns of growth, maintenance, and reproduction dictate the utilization of the resources acquired through foraging (Boggs 1992). Life history theory predicts that allocation decisions concerning the same resource within an individual organism (e.g., body reserves) lead to physiological trade-offs (Stearns 1992). Investment in current reproduction may impact survival or future fecundity by exposing adults to insurmountable recovery of body reserves resulting in a shortened life span (Calow 1979, Clutton-Brock 1984, Gustafsson and Pärt 1990, Daan et al. 1996) or reduced growth. Although measurement of trade-offs and assumptions of reproductive costs have elicited criticism (Tuomi et al. 1983, Partridge 1987), measures of physiological allocation have been important in identifying constraints on life history variation (e.g., Kenagy et al. 1990). Measures of variation in reproductive allocation are important in defining the conditions under which trade-offs might be observed, including potential compensation for somatic costs and energy thresholds for survival costs. A good physiological measure of reproductive effort is the proportion of energy devoted to reproduction and storage. In addition to energy al-

Manuscript received 15 November 1999; revised 28 August 2000; accepted 17 October 2000; final version received 2 January 2001.

${ }^{1}$ Present address: Department of Biology, Sonoma State University, 1801 E. Cotati Avenue, Rohnert Park, California 94982 USA. E-mail: crocker@ sonoma.edu location, a good measure of reproductive effort should consider variation in individual activity and foraging efficiency (Stearns 1992) and consider that energy expenditure is recoverable (Drent and Dann 1980).

Body size exerts an important influence on patterns of animal life-history traits, within (e.g., Martin 1987, Patton and Brylski 1987, Dobson 1992, Dobson and Michener 1995) and among species (Western 1979, Western and Ssemakula 1982, Stearns 1983, Dunham and Miles 1985, Costa 1991, 1993). Many studies have used mass as a preferred indicator of body size, but few have examined the impacts of both body mass and body condition on reproductive effort (e.g., Dobson and Michener 1995). Drent and Daan (1980) emphasized the importance of body condition on breeding success in birds and hypothesized that body reserves at the onset of reproduction impact the rate of energy expenditure during breeding. Even in species in which body reserves provide only a small portion of reproductive expenditure, reserves may be essential to supplement physiological limitations at peak energy demands on the rate of intake and digestion or to buffer short-term reductions in food availability (Tyler 1987). In many species it is difficult and time consuming to measure simultaneously the provisioning behavior of individual parents in relation to their own energy balance and energy delivery to the offspring (Weimerskirch et al. 1997). Capital breeders are species that store energy as body reserves that are used later for reproduction. Consequently, current and future repro- 
duction are linked through body reserves and variation in foraging efficiency and previous energy acquisition is directly measurable as body reserves at the onset of reproduction. These species provide ideal systems with which to examine potential constraints of physiology on reproductive allocation.

Mammalian reproduction is energetically expensive (Loudon and Racey 1987, Gittleman and Thompson 1988) and constraints that may limit a female's ability to allocate energy to reproduction are thought to have strong impacts on the variation of mammalian behavior and reproductive patterns (Thompson 1992). Characteristics of mating and breeding strategies (CluttonBrock et al. 1982, Altmann 1983, Ortiz et al. 1984, Lee and Moss 1986, Oliveras and Novak 1986, Trillmich 1986, Bermann 1988, Costa 1991) and life history tactics (McNab 1980, Henneman 1983, 1984, Martin $1984 a, b$, Harvey and Clutton-Brock 1985, Harvey 1986 , Lee 1987,1988 ) have been attributed to compromises necessitated by the high energy costs of reproduction and lactation (Hanwell and Peaker 1977, Peaker et al. 1984, Loudon and Racey 1987).

In phocid seals, the temporal and spatial separation of marine foraging and terrestrial parturition imposes energetic constraints that are likely to influence both the duration and magnitude of reproductive effort. The energy reserves obtained during foraging periods must support the energy costs of lactation as well as the maintenance metabolism of the mother. A female can maximize the amount of energy available for milk production by minimizing the amount expended on her own maintenance metabolism while on shore, thus reducing her metabolic overhead (Fedak and Anderson 1982). The ability of the mother to stay on shore and provision her pup is a function of the magnitude of her energy reserves and the rate at which she is able to provide milk energy to her pup. By increasing the rate of milk energy transfer and reducing the time spent on shore, metabolic overhead is minimized. Milk yield has been linked to body size in a variety of species (Brody 1945, Linzell 1972). Larger females may have an advantage in their ability to transfer energy rapidly and increase the efficiency of the translation of their energy expenditure into milk production that is opposed by higher metabolic rates associated with large body size. Most studies on large mammals have relied on milk output or pup growth as indexes of parental investment. Milk output, suckling frequency, or offspring growth studies may underestimate expenditures for maintenance and production of milk (Lucas et al. 1987, Oftedal and Gittleman 1988). Few studies have examined interindividual variation in the translation of maternal energy expenditure into milk energy or offspring benefit. We investigated the energetics of lactation in a capital breeder, the northern elephant seal (Mirounga angustirostris), to assess the effects of maternal traits, including mass, body composition, and age, on reproductive effort and milk energy delivery.
Northern elephant seals exhibit indeterminate growth with a resultant positive correlation between mass and age (Le Boeuf 1994). Assuming that reproduction imposes a cost, measured as a reduction in future fitness (Bell 1980) there should be a level of reproductive effort at each age that optimizes trade-offs between current and future reproduction (Willimas 1966). Life history theory predicts that reproductive effort will increase with age if residual reproductive value declines with age (Gadgil and Bossert 1970, Schaffer 1974, Pianka and Parker 1975, Charlesworth and Leon 1976). This prediction is favored when a species exhibits low mortality of breeding-age individuals, low rates of population growth, and indeterminate growth (Charlesworth 1980). In a rapidly expanding population, selection may favor early reproductive effort (Cole 1954, Lewontin 1965, Stearns 1976). In general, studies have supported the idea of a fitness cost associated with reproduction in elephant seals (Reiter and Le Boeuf 1991, Sydeman et al. 1991, Sydeman and Nur 1994). These costs were expressed as reduced survivorship and reduced future fecundity associated with age at first breeding. Reproductive value declines slowly from primiparity to age 11 , and then declines rapidly until the end of life (Reiter and LeBoeuf 1991). Weaning success increases asymptotically with increasing female age, most significantly between 3 and 6 yr of age (Reiter et al. 1981, Reiter and Le Boeuf 1991, Sydeman et al. 1991). Thus, decreasing costs to future reproduction and increasing benefits with increasing age may select for increasing maternal reproductive effort with age. In contrast, the high growth rate of the population (Stewart et al. 1994) may dramatically increase the value of offspring produced early in an individual's life span relative to those produced later in life. This may provide a selective pressure for increased reproductive effort in young females. In this study, we consider impacts of maternal mass, body composition, and age on reproductive expenditure and energy delivery to the offspring.

\section{Methods}

This study was conducted at Año Nuevo State Reserve, San Mateo County, California, during the 1991, 1992, 1995, and 1996 breeding seasons. Known age females were identified by numbered plastic flipper tags (jumbo roto-tags, Dalton Company, Oxon, UK), which were attached to animals after weaning in previous breeding seasons. Upon arriving at the rookery at the start of the breeding season, tagged females were marked with Lady Clairol hair dye (Clairol Incorporated, Stamford, CT). Pups born to marked females were marked with bleach as soon as possible after parturition to ensure identification throughout lactation and confirm that females were suckling their own pups. A sample of 27 mother-pup pairs was used with maternal ages ranging from 3 to $13 \mathrm{yr}$ old. All nonprimiparous females used in the study had attempted to 
breed the previous year. Experimental mother-pup pairs were observed after parturition to ensure that recognition between the two was established, the pup suckled only its mother, the mother nursed no other pups, and that maternal behavior was typical. Previous investigations of milk intake (Kretzmann et al. 1993) and maternal and offspring mass change (Deutsch et al. 1994) in northern elephant seals revealed no significant variation in reproductive effort with offspring sex. For this reason, no attempt was made to control for offspring sex.

A first treatment was performed $2-4(3.0 \pm 0.4) \mathrm{d}$ postpartum with a second treatment following at 2325 (23.4 \pm 0.7) d postpartum, just prior to weaning. Each female was immobilized with Telazol $(1 \mathrm{mg} / \mathrm{kg}$; Aveco, Fort Dodge, Indiana) by intramuscular injection. If necessary, subsequent immobilization was maintained by intravenous administration of ketamine $\mathrm{HCl}$.

\section{Maternal mass and body composition}

A portable ultrasound scanner (Ithaca Scanoprobe, Ithaca, New York) was used to measure blubber thickness. Dorsal, lateral, and ventral measurements were taken at each of six rings spaced along the long axis of the animal. Girth at each ring, the distance from the tail to each ring, and the total curved length of the animal were measured. From these data, a series of truncated cones was drawn that allowed the volumes of the blubber and nonblubber body compartments to be estimated. Assuming densities for the two compartments $(0.94 \mathrm{~g} / \mathrm{mL}$ and $1.1 \mathrm{~g} / \mathrm{mL}$ respectively), the relative proportion of mass was calculated (Gales and Burton 1987). This technique has been validated against isotopic methods of measuring body composition (Worthy et al. 1992, Webb et al. 1998).

The female was weighed on a canvas tarpaulin connected to a hand winch and a Chatillon scale (Chatillon, Brooklyn, New York, capacity $1000 \pm 5 \mathrm{~kg}$ ), or an MSI tension dynamometer (MSI, Seattle, Washington, capacity $1000 \pm 2 \mathrm{~kg}$ ) suspended from an aluminum tripod. As an internal validation to the body composition determination, masses were calculated based on volume calculations and density assumptions and compared with measured masses. Calculated masses were within an average of $4 \%$ of measured masses. Rates of adipose tissue and lean tissue loss were used to extrapolate to weaning if the female remained on land for 1-3 d after the second treatment.

\section{Pup mass and body composition}

Pup mass and body composition measurements were made for 16 of the mother-pup pairs. For the first treatment, after immobilization of the mother, the pup was removed and injected with $61.4 \mathrm{MBq}$ HTO in $5 \mathrm{~mL}$ of sterile saline. The pup was then returned to its mother. The syringe used for this injection was gravimetrically calibrated to determine injection volume precisely. Af- ter a 3-h period in which the isotope equilibrated with the animal's total body water pool (Costa et al. 1986), the pup was retrieved and a blood sample $(10 \mathrm{~mL})$ was collected. The second treatment followed an identical procedure, except that a pre-injection blood sample was obtained in order to determine residual isotope specific activity, and the pup was injected with $37 \mathrm{MBq}$ HTO in $3 \mathrm{~mL}$ of sterile saline. In both treatments, the pup was weighed in a canvas restraint bag attached to a hand winch and a Chatillon WT-10 scale (capacity 250 $\pm 2 \mathrm{~kg}$ ) suspended from an aluminum tripod.

Blood samples were collected in serum vacutainers, centrifuged, and frozen as serum until analysis. The samples were thawed and the water was immediately extracted using vacuum distillation (Vaughan and Boling 1961). The specific radioactivity of each sample was assessed in triplicate. Two hundred $\mu \mathrm{L}$ of sample water was assayed in $9 \mathrm{~mL}$ of Betaphase scintillation cocktail (Westchem, San Diego, California) using a Beckmann model LS 3801 liquid scintillation counter (Beckmann, Orange County, California). Total body water (TBW) was calculated as the total amount of radioactivity injected divided by the radioactivity of the post-equilibration sample. The specific activity of the pre-sample was subtracted for the second treatment. The TBW numbers obtained from this analysis were decreased by $4 \%$, as the tritiated water dilution method slightly overestimates TBW volume (Nagy and Costa 1980, Reilly and Fedak 1991).

This assessment of TBW was used to estimate body composition by assuming that lipid has no free water and that fat-free mass has a hydration state of $73.3 \%$ free water (Worthy et al. 1992, Iverson et al. 1994). Lipid mass was calculated as: (body mass) -1.37 (TBW). Rates of adipose and lean tissue gain were used to extrapolate to weaning for pups whose mothers stayed 1-3 d after the second treatment. Pups were weighed after weaning and these masses were compared to those obtained by extrapolating mass gain of each tissue compartment. Extrapolated weaning masses were within $2 \%$ of measured masses.

\section{Pup metabolism estimates}

To accurately estimate milk intake from water flux, it is necessary to estimate metabolic water production and hence metabolism for each pup. Initial studies utilizing this methodology used a value measured from fasting weaned pups (Ortiz et al. 1984). A subsequent study on maternal investment used the doubly-labeled water technology to obtain metabolism measurements on 10 pups during the second week of lactation (Kretzmann et al. 1993). Mass specific metabolic rate should decrease somewhat with increasing body size and blubber content. To obtain a more representative estimate of pup metabolic water production, we used the same methodology to measure metabolism in five pups during the third week of lactation and combined these data with that from Kretzmann et al. Pups were removed 


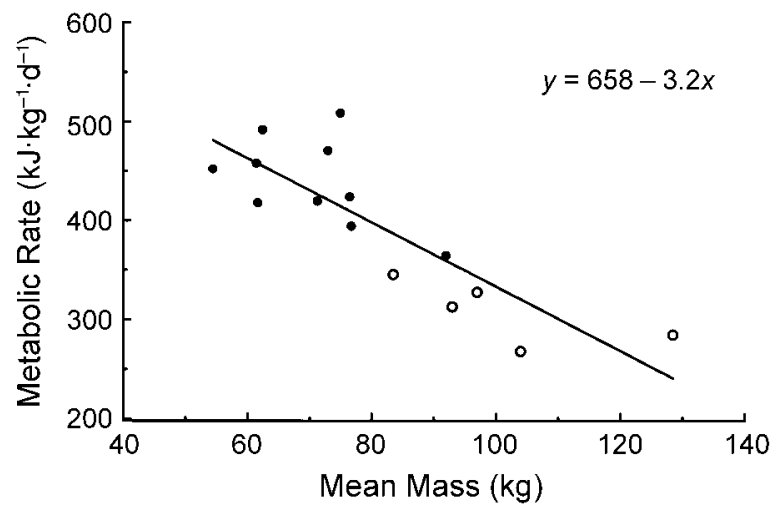

FIG. 1. Mass-specific metabolic rate of suckling pups in relation to mean body mass over the measurement interval $\left(r^{2}=0.70, F_{1,13}=30.2, P<0.01\right)$. Metabolic rate was measured as carbon dioxide production by doubly labeled water using equations from Nagy (1980). Closed circles are measurements from the second week of lactation from Kretzmann et al. (1993). Open circles are from the third week of lactation from the present study. This regression was used to estimate pup metabolic water production in milk intake measurements.

from their mother at $2 \mathrm{wk}$ of age, weighed, and a preinjection blood sample $(10 \mathrm{~mL})$ was taken for determination of background ${ }^{18} \mathrm{O}$ level. Pups were injected intraperitoneally with $61.4 \mathrm{MBq}$ of HTO in a $5 \mathrm{~mL}$ volume and $50 \mathrm{~mL}$ of ${ }^{18} \mathrm{O}$ water $(\sim 10 \%$ enrichment). Syringes were gravimetrically calibrated to accurately determine injection volume. After the 3-h equilibration period, pups were recaptured and blood sampled. After $7 \mathrm{~d}$, a blood sample was obtained for determination of ${ }^{18} \mathrm{O}$. The pup was again weighed, injected with $37 \mathrm{MBq}$ HTO in a $3 \mathrm{~mL}$ volume, allowed to equilibrate, and blood sampled in order to measure changes in TBW over the measurement period. Blood samples were centrifuged and immediately frozen as serum until analysis. The samples were thawed and water was immediately extracted and analyzed for HTO as previously described. ${ }^{18} \mathrm{O}$ concentrations were analyzed by Metabolic Solutions, Stamford, Connecticut, through mass ratio spectrometry. Turnover measurements were used to calculate metabolism (mass specific $\mathrm{CO}_{2}$ production per unit time), using the equation from Nagy (1980). These data were combined with those from Kretzmann et al. (1993) to obtain a regression line relating mass specific metabolic rate to pup mass $\left(r^{2}=0.70, P<\right.$ 0.01 ; Fig. 1). This regression equation was used to estimate metabolism and metabolic water production for each pup used in the milk intake study.

\section{Milk energy estimates}

Milk intake measurements were made for 16 of the mother-pup pairs. Milk samples were obtained from each female during each treatment. Females were injected with 60 IU of oxytocin and milk was manually expressed using a modified $20 \mathrm{~cm}^{3}$ syringe. The lipid, protein, water, and ash components of the milk were measured independently, using $1 \mathrm{~mL}$ aliquots. Lipid content was measured using a modified version of the Roese-Gottleib method (Horwitz 1975). Six extractions with ether and petroleum were performed to ensure complete lipid extraction. A modified Kjeldahl procedure was used to measure total nitrogen. This value was used to calculate protein content as total nitrogen $\times 6.38$. Water content for each milk sample was assessed by oven drying for $48 \mathrm{~h}$ at $90^{\circ} \mathrm{C}$. Ash content was assessed gravimetrically after samples were incinerated in a muffle furnace for $24 \mathrm{~h}$ at $550^{\circ} \mathrm{C}$. Milk samples were analyzed in duplicate and the sum of the individual components totaled $98-102 \%$ of the initial sample mass.

An estimate of milk intake was calculated from rates of tritiated water turnover, the calculated average proportion of water in each female's milk, and an estimate of metabolic water production (Oftedal and Iverson 1987, Kretzmann et al. 1993). Water efflux rate $\left(r_{\text {ef }}\right)$ was determined from the change in the specific activity between the first treatment post-equilibration sample and the second treatment pre-injection sample. Mean daily water influx rate $\left(r_{\text {in }}\right)$ was calculated as

$r_{\mathrm{ef}}+2000\left(\mathrm{TBW}_{2}-\mathrm{TBW}_{1}\right) /\left[\left(t_{2}-t_{1}\right)\left(M_{1}+M_{2}\right)\right]$

where $\left(t_{2}-t_{1}\right)$ is the elapsed time between treatments (Nagy and Costa 1980). The milk intake rate $\left(M_{\mathrm{i}}\right)$ was calculated as $\left(r_{\text {in }}-r_{\text {ox }}\right) / W$, where $r_{\text {ox }}$ is the rate of oxidatively formed water and $W$ is the calculated average proportion of water in each individual's milk. We calculated $r_{\text {ox }}$ with the conversion factor of $0.02629 \mathrm{~g} \mathrm{H}_{2} \mathrm{O}$ / kJ (Schmidt-Neilsen 1975), using the pup's average mass and the regression equation from Fig. 1. The total milk intake for each pup $\left(M_{\mathrm{t}}\right)$ was calculated as: $M_{\mathrm{i}} \times$ lactation duration (d). This method of estimating milk intake assumes that oxidative water production and milk water are the only significant sources of water input.

\section{Energetic estimates}

The energy represented by mass and body composition changes was calculated as the energy that could be obtained by metabolizing the mass of protein or lipid gained by the pup or lost by the female $(17.99 \mathrm{~kJ} / \mathrm{g}$ and $39.33 \mathrm{~kJ} / \mathrm{g}$, for protein and lipid, respectively; Costa 1987). Lean tissue was assumed to be $73 \%$ water and $27 \%$ protein. For females, blubber was assumed to be $10 \%$ water, $90 \%$ lipid. To validate this method of calculating the energy represented by loss of blubber in the lactating females, 2-6 $\mathrm{mm}$ blubber biopsies were obtained from eight study females, four early and four late lactation, and $10 \mathrm{~g}$ blubber samples were obtained from three separate recently dead females late in lactation. Blubber samples were oven dried at $90^{\circ} \mathrm{C}$ for $72 \mathrm{~h}$ to assess water content. Water content of adult female blubber was $9.7 \pm 0.3 \%(n=11)$. Early lactation water content was not significantly different from late lacatation. Energy density, determined by bomb 


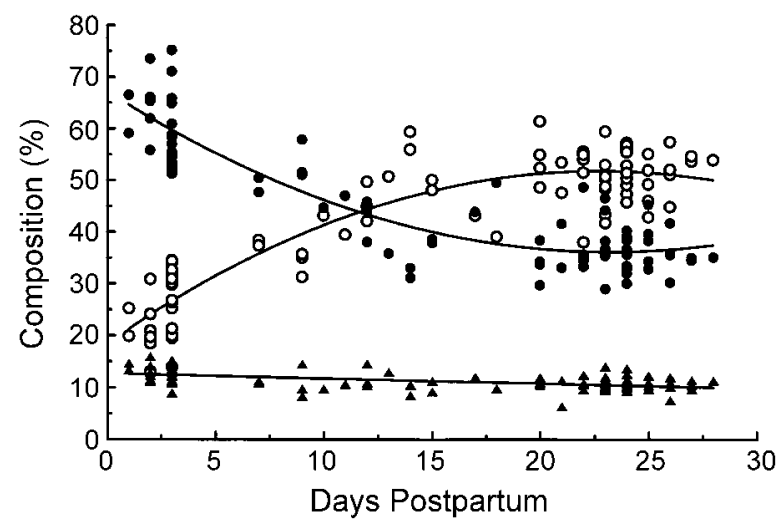

FIG. 2. Changes in the proximate composition of milk over the lactation interval. Open circles are lipid content, closed circles are water content, and triangles are protein content. Data are from Riedman and Ortiz (1979), Kretzmann et al. (1993), and the Results. Regression equations: lipid, $y$ $=18.4+2.94 x-0.06 x^{2}, r^{2}=0.24, F_{1,85}=27.5, P<0.01$; water, $y=62.3-2.68 x+0.06 x^{2}, r^{2}=0.82, F_{1,85}=191.3$, $P<0.01$; protein, $y=-12.7-0.09 x, r^{2}=0.80, F_{1,85}=$ 185.2, $P<0.01$.

calorimetry was $35.1 \pm 1.3 \mathrm{~kJ} / \mathrm{g}(n=8)$. This value was similar to that obtained by assuming the measured water content and energy value for lipids.

An average energetic density was calculated for each female's milk using the two endpoint milk compositions and a curve derived using milk composition data from this study and all previous studies on northern elephant seals (Riedman and Ortiz 1979, Kretzmann et al. 1993; Fig. 2). Protein values from Riedman and Ortiz (1979) were calculated using an inappropriate standard (C. L. Ortiz, personal communication) and were therefore increased by a constant $(3.0 \%)$. Average energy density was calculated from a value for each milk component. This value was obtained for lipid and water content by integrating over the largest portion of the curve for each component that could connect the two endpoints. As the change in milk protein content over lactation was monotonic, the two endpoints were averaged. This method yielded independently derived mean compositions for each of the milk components, which summed to within 95-100\%. Protein and lipid components were multiplied by their energy equivalents to obtain a mean energy density for each female's milk. Milk energy production was calculated by multiplying the total milk intake $\left(M_{\mathrm{t}}\right)$ for each pup by the estimated energy density of each mother's milk. Metabolic overhead was calculated as the proportion of maternal energy expenditure not accounted for by milk energy production.

\section{Path analysis}

Path analysis (Li 1981, Pedhazur 1982) was used to evaluate the influences of maternal mass, body composition, and age on energy expenditure, milk energy, and energy stored by offspring. A path coefficient is a standardized partial regression coefficient, representing the expected change in a dependent variable in units of its own standard deviation to a change in an independent variable equal to its own standard deviation, with other independent variables held constant. This method is useful in partitioning the correlation between variables into direct causal effects and effects due to other associations among other variables (Schemske and Horvitz 1988, Mitchell 1992). For statistical analysis we used the STB option of the REG procedure in SAS (1990).

\section{RESUlts}

\section{Mass and body composition change}

Mean absolute mass loss of mothers extrapolated to weaning was $169 \pm 20 \mathrm{~kg}$ or $35.8 \pm 3.6 \%$ of initial body mass. Mass loss increased significantly with increasing maternal parturition mass $(r=0.73, P<$ $0.01)$. The mean rate of mass loss was $7.5 \pm 0.9 \mathrm{~kg} /$ d. The rate of mass loss increased significantly with initial maternal mass $(r=0.62, P<0.01)$. During the nursing period, pups in the sample gained a mean of $90 \pm 27 \mathrm{~kg}$ or $20.3 \pm 2.2 \%$ of the mother's initial body mass at a rate of $3.8 \pm 1.2 \mathrm{~kg} / \mathrm{d}$. Mean weaning mass was $141 \pm 18 \mathrm{~kg}$. Mean efficiency of mass transfer between mother and pup was $53 \pm 15 \%$.

Females lost an average of $57.3 \pm 5.2 \%$ of their body fat during lactation and $24.8 \pm 4.3 \%$ of their body protein. At weaning, mothers were $23.1 \pm 1.4 \%$ adipose tissue $(20.8 \pm 1.3 \%$ fat $)$ and $20.8 \pm 0.4 \%$ protein. On average, mass lost was composed of $52.6 \%$ fat, $15.3 \%$ protein, and $32.1 \%$ water. Mass gained by the pups was on average $55.2 \%$ fat, $10.5 \%$ protein, and $34.3 \%$ water. At weaning, mean pup body composition was $41.6 \pm 4.2 \%$ fat and $10.6 \pm 1.3 \%$ protein.

\section{Lactation energetics}

Females expended a mean of $3490 \pm 490 \mathrm{MJ}$ over lactation, depleting $48.0 \pm 3.0 \%$ of their total body energy. Mean rate of energy expenditure was $177 \pm$ $31 \mathrm{MJ} / \mathrm{d}$ or $5.7 \pm 0.9$ times standard metabolic rate (SMR) predicted by the equation, $\mathrm{SMR}=0.293 \mathrm{~W}^{0.75}$ $\mathrm{MJ} / \mathrm{d}$ (Kleiber 1975). This general relationship between SMR and body mass in mammals has been discussed and confirmed for seals by Lavigne et al. (1986). Milk production accounted for $60.0 \pm 8.6 \%$ of maternal energy expenditure, with the remaining $40.0 \%$ going toward metabolism. Mean calculated metabolic rate for females was $74 \pm 20 \mathrm{MJ} / \mathrm{d}$ or $2.40 \pm 0.94$ times the predicted SMR. Fuel substrates were estimated by assuming that protein and lipid losses not accounted for by milk constituents were burned for metabolism. These data indicate that 9.8 . $\pm 5.3 \%$ of maternal metabolism was met through protein catabolism with the remainder being met through lipid catabolism. Mean total milk energy delivered was $2183 \pm 552 \mathrm{MJ}$ and varied by as much as $163 \%$ between seals. Mean ab- 
solute pup energy gain was $2031 \pm 243 \mathrm{MJ}$. Pups stored $83.6 \pm 2.0 \%$ of the energy derived from milk, using $17.4 \%$ for metabolism. Mean efficiency of energy transfer between mother and pup was $58.4 \pm 8.4 \%$. Maternal energy expenditure was not significantly correlated with milk energy production $(r=0.32, P>$ 0.05). Pup energy gain varied significantly with milk energy intake $(r=0.77, P<0.01)$.

\section{Effects of mass}

Variation in absolute measures of investment with maternal parturition mass are shown in Fig. 3. Maternal parturition mass was significantly related to both energy expenditure and the rate of energy expenditure over the lactation interval (Fig. 3a, c, Table 1). Both total milk energy and the rate of milk energy production were significantly correlated with parturition mass (Fig. 3e, g, Table 1). Energy stored by the pup increased significantly with maternal parturition mass (Fig. 3i, Table 1). Females varied in their ability to translate their energy expenditure into milk production. Metabolic overhead, as a proportion of total energy expenditure, varied indirectly with mean maternal mass over the lactation period (Fig. 4a).

\section{Effects of body composition}

When controlled for maternal parturition mass, energy expenditure increased significantly with increasing initial adipose tissue proportions (Fig. 5a). Together, maternal mass and body composition were highly significant predictors of total energy expenditure over lactation (Fig. 6), accounting for $85 \%$ of the variation in energy expenditure. Parturition body composition had impacts on the proportions of mass lost from adipose and lean tissue compartments. The proportion of mass loss represented by lean tissue was negatively related to initial body composition (Fig. 7), with fatter females losing proportionally less lean tissue over lactation.

\section{Effects of maternal age}

Variation in absolute measures of investment with maternal age are shown in Fig. 3. Maternal age was positively correlated with maternal parturition mass $(r$ $=0.72, P<0.01)$. Total energy expended was significantly correlated with maternal age (Fig. 3d, Table 1), although the rate of energy expenditure was not (Fig. $3 \mathrm{~b}$, Table 1). There was a trend of decreasing energy expenditure as a proportion of total body energy with age that was not statistically significant $(r=0.41, P$ $>0.05$ ) and the range of variation was small (44-55\%). Mass-specific energy expenditure demonstrated a significant negative correlation with maternal age (Table 1 ). When the residuals of the regression of energy expenditure vs. mass within the sample were used to control for mass, this relationship was not evident and energy expenditure was not significantly correlated with maternal age (Fig. 5b, Table 1). Maternal adipose body composition at weaning was similar for all females $(23.1 \pm 1.4 \%)$ and was not related to age. Age was a significant predictor of both milk intake rate and total milk energy (Fig. 3f, h, Table 1). Metabolic overhead as a percentage of total energy expenditure decreased significantly with maternal age (Fig. 4b). Energy storage by the pup was significantly correlated with maternal age (Fig. 3j, Table 1). When energy storage by the pup was controlled for maternal parturition mass, no relationship to maternal age was evident (Table 1).

\section{Path analysis}

We used path analysis to examine characteristics of mothers as causal explanation or variation in energy expenditure during reproduction (Fig. 8). Multiple regressions revealed that a significant proportion of the variation in energy expenditure (EE), milk energy (ME), and offspring energy storage (OE) could be explained by the independent variables chosen for the path diagram (EE, $R^{2}=0.85, F=45.9$, df $=3,27, P$ $<0.01$; ME, $R^{2}=0.53, F=4.5$, df $=3,16, P<0.05$; OE, $R^{2}=0.58, F=5.5$, df $\left.=3,16, P<0.05\right)$. There were significant positive path coefficients from mass and body composition to energy expenditure. Effects of maternal age on energy expenditure were not significant. There were significant, positive, but weaker, path coefficients from mass and body composition to milk energy and the unexplained variance was significant. There were no significant path coefficients from the independent variables to offspring energy storage, but maternal age effects had become stronger. Multiple regressions revealed that the independent variables explained a significant proportion of the variation in metabolic overhead $\left(R^{2}=0.50, F=4.4\right.$, df $=3,16, P<$ $0.05)$. There was a significant negative path coefficient from maternal age to metabolic overhead. Effects of parturition mass and body composition on metabolic overhead were not significant.

\section{DISCUSSION}

The mass of the mother at parturition appears to be the most important determinant of the energetic component of reproductive effort in northern elephant seals. Path analysis revealed strong impacts of maternal mass and body composition on energy expenditure and milk energy delivered. The size and blubber reserves obtained by the female during her biannual foraging migrations appear to determine the level of reproductive expenditure in the subsequent breeding episode. Variation in the energetic component of reproductive effort was not associated with age for parous females, although older females were able to devote a larger proportion of their energy expenditure to milk production. Age-related changes in maternal behavior, such as increasing dominance, more central harem position, and increased weaning success have been documented (Le Boeuf and Reiter 1988, Sydeman et al. 1991) and at- 

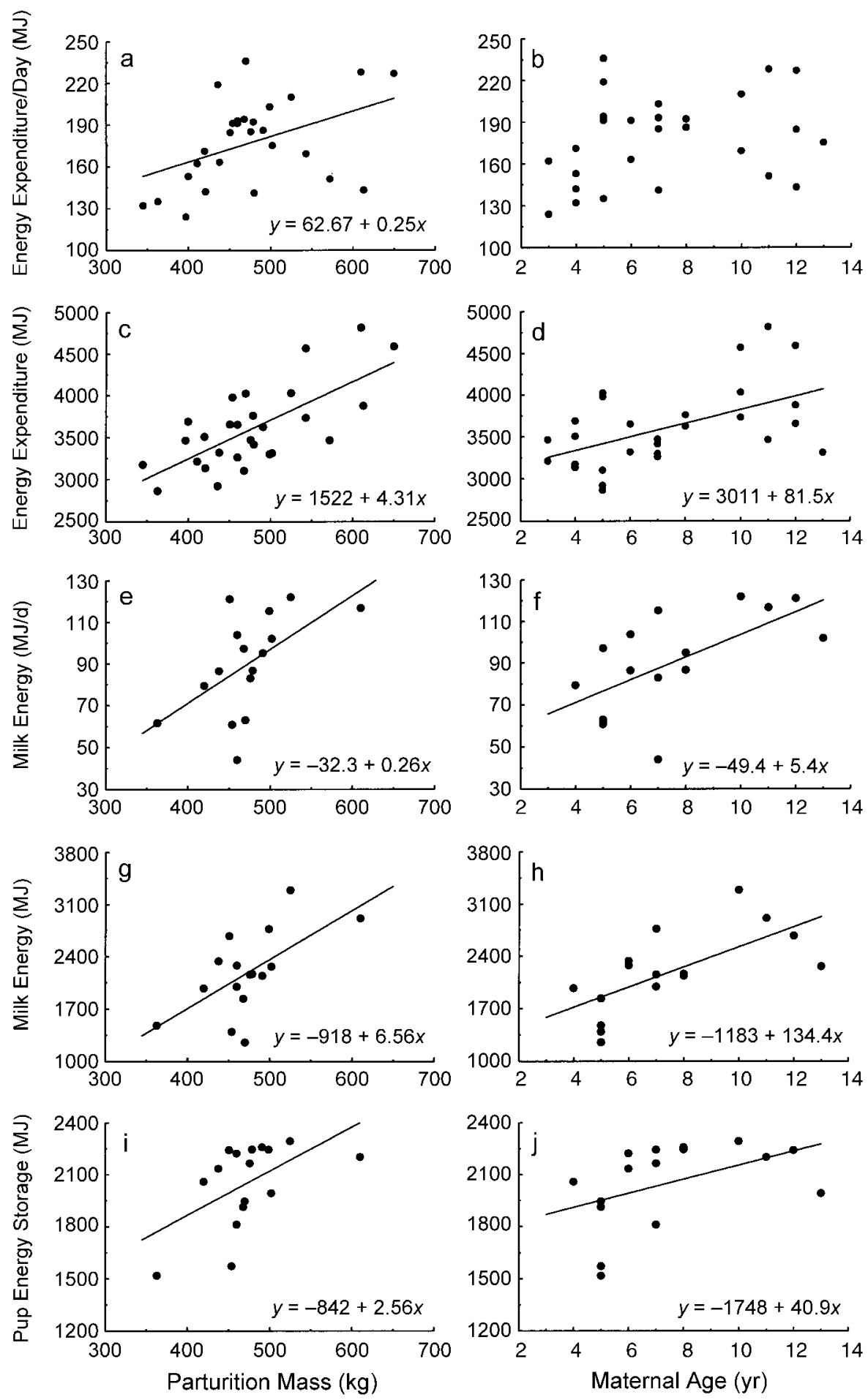

FIG. 3. Absolute measures of maternal investment as a function of parturition mass and age: (a, b) average daily energy expenditure by mother; (c, d) total energy expenditure by mother; (e, f) average daily milk energy; $(g, h)$ total milk energy; $(i, j)$ total energy stored by the pup. See Table 1 for sample sizes, correlation coefficients, and levels of significance. 
TABLE 1. Pearson product-moment correlation coefficients $(r)$ between absolute and relative measures of reproductive effort (RE) and maternal parturition mass, body composition, and age.

\begin{tabular}{|c|c|c|c|c|c|c|}
\hline \multirow[b]{3}{*}{ Measure } & \multirow{2}{*}{\multicolumn{2}{|c|}{$\begin{array}{c}\text { Absolute measures } \\
\text { of RE vs. }\end{array}$}} & \multirow{2}{*}{\multicolumn{2}{|c|}{$\begin{array}{c}\text { Mass-specific } \\
\text { measures of RE } \dagger \text { vs. }\end{array}$}} & \multicolumn{2}{|c|}{ Adjusted RE $\ddagger$ vs. } \\
\hline & & & & & \multirow[b]{2}{*}{ Age } & \multirow{2}{*}{$\begin{array}{l}\text { Composi- } \\
\text { tion§ }\end{array}$} \\
\hline & Mass & Age & Mass & Age & & \\
\hline \multicolumn{7}{|l|}{ Mother $(n=27)$} \\
\hline Energy expenditure/d & $0.44 *$ & 0.15 & $-0.40^{*}$ & $-0.42 *$ & -0.10 & 0.09 \\
\hline Total energy expenditure & $0.73 * *$ & $0.52 *$ & -0.11 & -0.13 & 0.01 & $0.83 * *$ \\
\hline Lactation duration & -0.05 & -0.05 & N/A & N/A & N/A & N/A \\
\hline \multicolumn{7}{|l|}{ Milk $(n=16)$} \\
\hline Milk energy/d & $0.57 *$ & $0.63 * *$ & 0.10 & 0.36 & 0.35 & 0.37 \\
\hline Total milk energy & $0.64 * *$ & $0.68 * *$ & 0.27 & 0.46 & 0.38 & $0.50 *$ \\
\hline Milk production efficiency\| & 0.35 & 0.40 & N/A & N/A & N/A & N/A \\
\hline \multicolumn{7}{|l|}{ Pup $(n=16)$} \\
\hline Energy storage/d & 0.38 & 0.44 & -0.39 & -0.33 & N/A & N/A \\
\hline Energy storage & $0.57 *$ & $0.48 *$ & -0.31 & -0.02 & 0.16 & -0.14 \\
\hline Energy transfer efficiency $\mathbb{I}$ & -0.23 & 0.12 & N/A & N/A & N/A & N/A \\
\hline
\end{tabular}

Note: $\mathrm{N} / \mathrm{A}=$ not applicable.

$\dagger$ Mass-specific measures of RE are expressed per kilogram of parturition mass.

Variables that were significantly correlated with mass were adjusted for maternal mass by regressing them against parturition mass and then correlating the residuals with maternal age and composition.

$\S$ The proportion of body mass composed of adipose tissue.

|| Milk energy delivered/maternal energy expenditure.

II Pup energy storage/maternal energy expenditure.

$* P<0.05$; ** $P<0.01$.

tributed to increased reproductive effort. These changes do not appear to be associated with increased proportional maternal energy expenditure and may be strongly impacted by collateral advantages of maternal age and body size. Variation in milk energy delivered to the pup appeared to be primarily the result of effects of body size and body composition on milk yield and increased milk production efficiency via reduced metabolic overhead with increasing age. Path analysis suggested that mass effects on efficiency are insignificant and that maternal age is the most important influence on the efficiency of lactation. It has been suggested that one strategy available in the case of energy limitations on allocation toward reproduction is compensatory shifts in behavior that reduce energy spent on activity and reduce maternal energy requirements (Thompson 1992). The present study suggests that older, more experienced females are able to devote a higher proportion of their energy expenditure to milk production, and a smaller proportion toward other activities associated with securing a position in a harem and breeding that are reflected in maternal metabolism values. If older, larger females are able to succeed more readily in dominance interactions and secure a central harem position, they are less likely to devote as much energy toward winning future competitive interactions with other females and protesting harassment by subordinate males on the harem periphery. In this way, older females might use age and size as collateral advantages to achieve better breeding locations and increase milk energy production with a similar proportional energy expenditure.

Two effects demonstrated in previous studies led us to expect the reproductive effort of reproductively mature but physically immature females would be less than that of larger, older females. First, breeding early seems to impose fitness costs, expressed as reduced survival and fecundity (Reiter and Le Boeuf 1991, Sydeman et al. 1991). Second, weaning success increases with age, especially from puberty to physical maturity. Decreasing fitness costs and increasing reproductive benefits with age during the period between sexual and physical maturity should select for reduced effort in younger animals. We offer a number of nonexclusive explanations for the lack of age-related variation in reproductive expenditure when controlled for body mass and composition and significant physiological correlates of energy expenditure during reproduction.

For age-specific differences in reproductive effort to be evident, the ultimate fitness costs of reproduction in terms of reduced survival and future investment must be related to the proximate energy costs associated with breeding, though probably in a nonlinear fashion. This is suggested to some extent by the rise in mortality and decreased future fecundity associated with early primiparity (Reiter and Le Boeuf 1991, Sydeman et al. 1991). One explanation for a lack of age-related variation in reproductive effort is that seals are able to tolerate depletion of body reserves up to some physiologically determined threshold level, and only when 

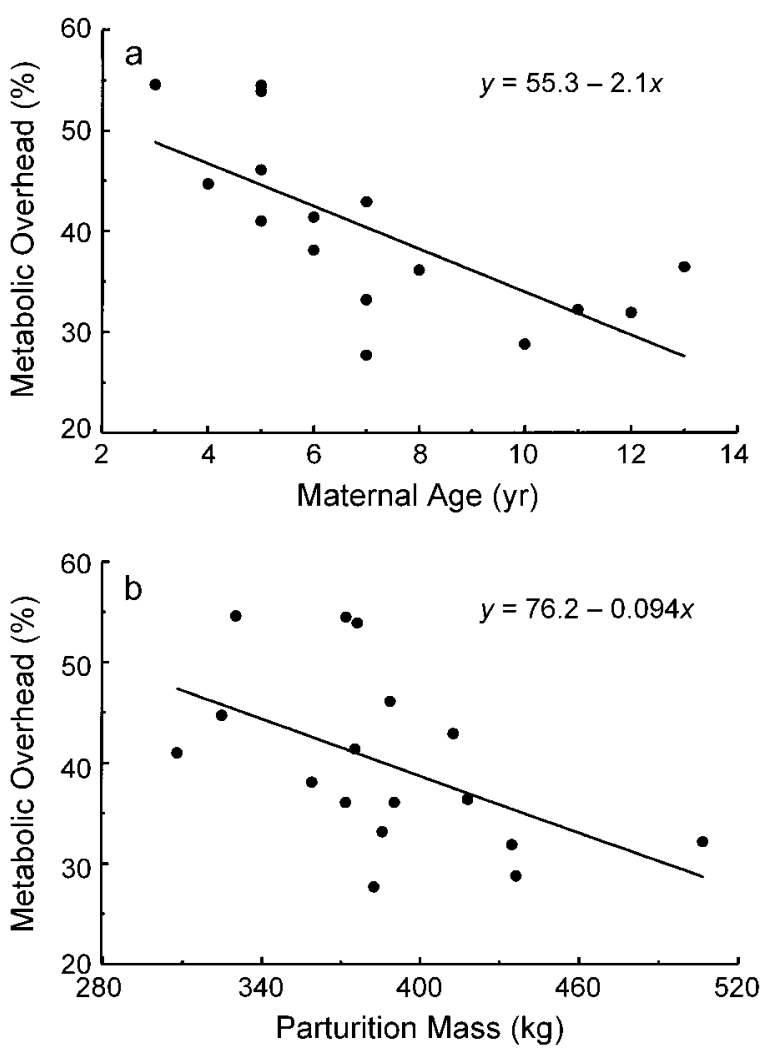

FIG. 4. Maternal overhead in relation to (a) maternal age $\left(r^{2}=0.50, F_{1,15}=15.0, P<0.01\right)$ and (b) parturition mass $\left(r^{2}=0.26, F_{1,15}=5.38, P<0.05\right)$. Metabolic overhead was calculated as the proportion of the average rate of energy expenditure by mothers that was not accounted for by the average rate of milk energy delivered.

that individual level is exceeded does the cost of reproduction become apparent (Tuomi et al. 1983). Circumstantial evidence for such a threshold includes the fact that the proportion of female body fat at the end of lactation lies within a narrow range, despite large variation in initial fat stores, in the duration of lactation, in absolute rates of mass loss, and in proportions of lean and adipose tissue loss. Crocker et al. (1998) showed that two key components of phocid fasting physiology, effective protein sparing and reduced renal filtration, have changed dramatically by the end of lactation and suggested that body composition may serve as a proximate mechanism to initiate weaning by impacting rates of lean tissue catabolism. The impact of body composition on proportional lean tissue loss in the present study supports this idea. This mechanism may result in termination of investment prior to levels that carry fitness consequences. This is most evident in large females that wean their pups and return to sea despite energy reserves greater than the smallest females at parturition. It is significant that despite remaining blubber reserves, females have depleted $25 \%$ of their total body protein stores. This is approaching the value of $30 \%$ suggested to be extreme in humans
(Cahill 1978). A female exceeding a hypothetical threshold depletion of body reserves might deplete muscle or vital organs or reduce its blubber layer below that which is required for thermoregulation at sea. If the physiological correlates of reproductive effort in the present study do stem from strong rises in fitness costs with investment past a threshold maternal body composition, only females at the end of their reproductive life spans might be expected to exhibit increased proportional reproductive effort or terminal investment (Clutton-Brock 1984). Females as old as 18 yr breed successfully at Año Nuevo (Reiter and Le Boeuf 1991). This extreme age class was rare, thought to represent an immobilization risk, and not included in the present sample.

There were no short-term survival impacts evident for any age class female from the level of energy expenditure measured in this study. All of the experimental females were observed to breed in the two years following the study. In general, previous studies have shown that adult mortality rates are low and females exhibit indeterminate growth despite consistent breeding (Deutsch et al. 1994), recovering not only the energy expended in reproduction, but increasing their energy stores available for reproduction in the subsequent year. This suggests that northern elephant seals are par-

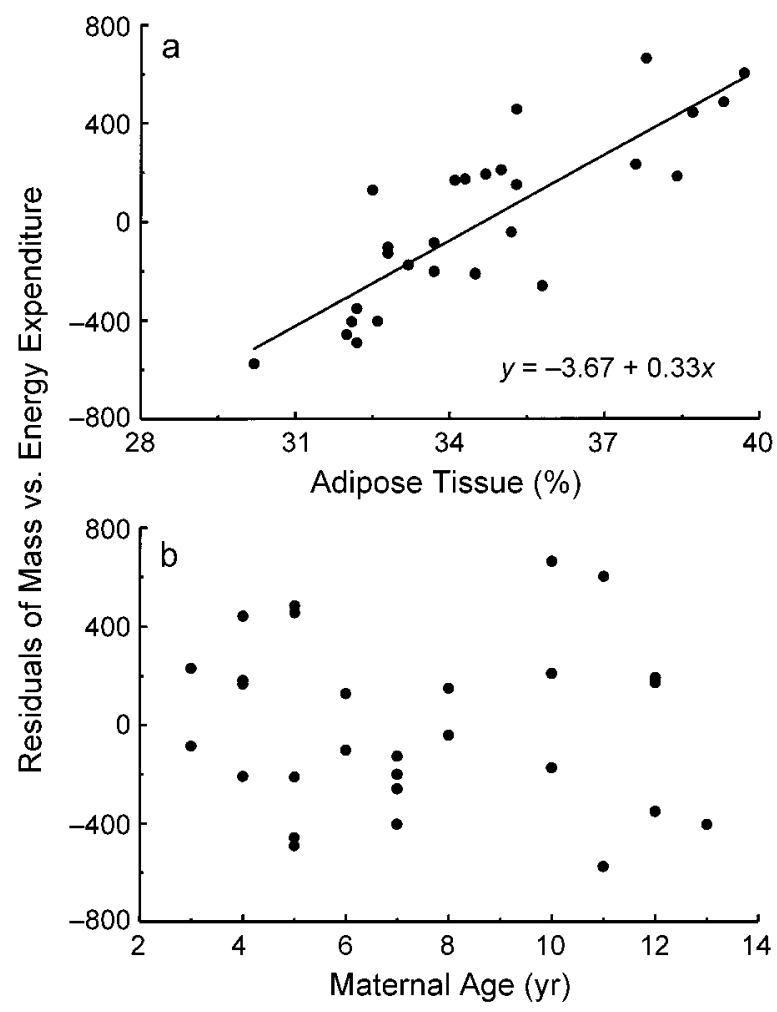

FIG. 5. Residuals of the regression of parturition mass vs. total energy expenditure (Fig. 3c) in relation to (a) parturition body composition estimated as percentage of adipose tissue from the truncated cones method $\left(r^{2}=0.69, F_{1,26}=56.7, P\right.$ $<0.01)$ and (b) maternal age $(r=0.01, P>0.05)$. 


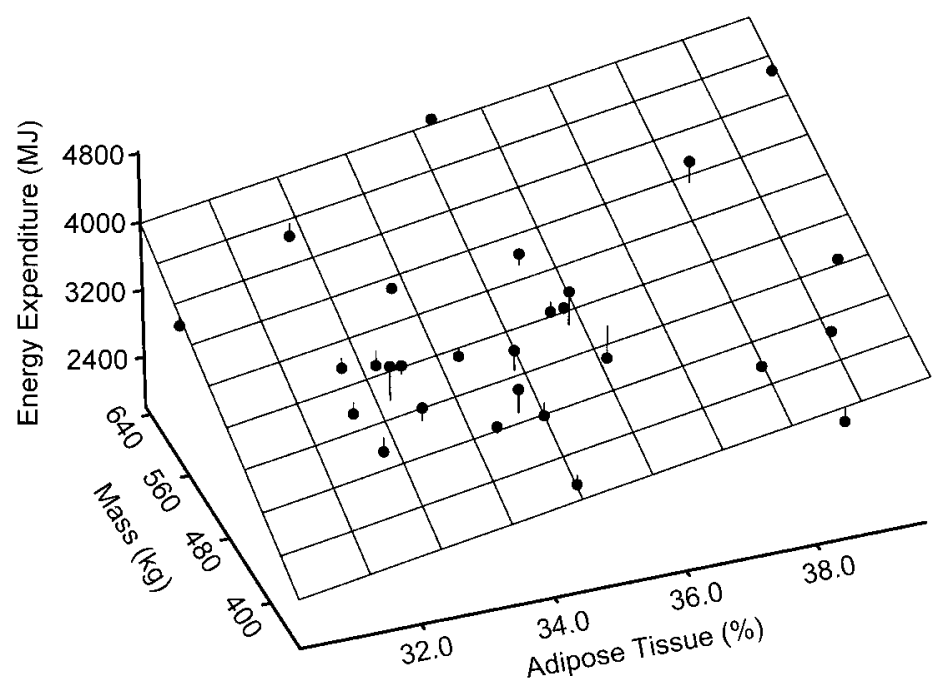

FIG. 6. Maternal energy expenditure (EE) over lactation in relation to parturition body composition (BC) and mass (M). Drop lines are residuals from the regression plane: $\mathrm{EE}=$ $-3063+119.2 \mathrm{BC}+5.3 \mathrm{M}, r^{2}=0.85, F_{2,25}=$ $71.7, P<0.01$. ticularly well suited to withstand the energy expenditure associated with reproduction with little effect on future survival or fecundity. Loss of a significant proportion of body mass (33-40\%) is a normal part of the annual cycle of both sexes of elephant seals (Costa et al. 1986, Deutsch et al. 1990, Worthy et al. 1992, Deutsch et al. 1994). Although there was wide variation in maternal energy reserves at the onset of lactation and wide variation in the level of investment given to offspring, females were more similar in the proportion of their energy reserves used in reproduction (44-55\% of body energy). This situation, where the variation among individuals in energy acquired is large, but the variation in the fraction allocated to reproduction is small, has been identified as potentially leading to a positive correlation between reproduction and survival (Van Noordwijk and de Jong 1986). While this costbased explanation is feasible, the phenotypic trade-off between growth and reproduction seems difficult to

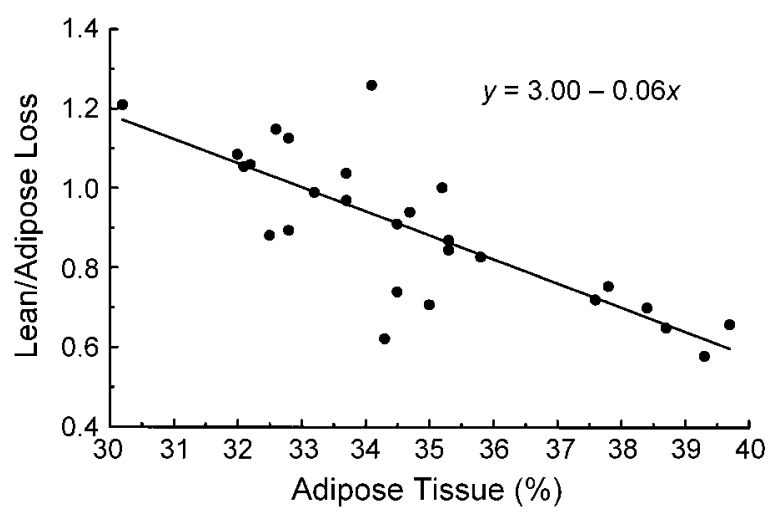

FIG. 7. Ratio of the rate of lean tissue loss to the rate of adipose tissue loss in relation to maternal body composition at parturition $\left(r^{2}=0.62, F_{1,25}=40.5, P<0.01\right)$. Body composition was estimated as percentage adipose tissue from the truncated cones method. avoid (e.g., Green and Rothstein 1991) unless females can compensate through increased foraging effort. The strong impacts of body reserves on expenditure suggest that reduced growth resulting from breeding might impact energy expenditure in subsequent years. Studies on reproduction and fecundity have suggested that there is depensating dependence, where unsuccessful females are less likely to be successful in the following year, between reproduction attempts early in life (Le Boeuf et al. 1989, Sydeman and Nur 1994) and potential compensating dependence, where unsuccessful females are more likely to be successful in the following year later in life (Sydeman and Nur 1994). This pattern is not consistent with a fecundity trade-off based on energy costs of reproduction, which the present study suggests would be most likely found in young individuals. This pattern is more consistent with an increase in weaning success with maternal experience in young animals that appears to plateau and then decline for very experienced females (Sydeman et al. 1991). This increase in reproductive performance with experience may be an important selective force for high levels of expenditure in young females, despite potential fitness costs.

If maternal size and energy stores are the major determinants of the level of investment and these factors increase with age, we would most likely observe fitness costs in young primiparous individuals who attempt to breed with significantly lesser body reserves than older females. Based on curves from the present study, a typical 3-yr-old female, weighing $370 \mathrm{~kg}$ and composed of $35 \%$ adipose tissue at parturition, will expend 3070 MJ in body reserves during lactation, delivering 1566 MJ of milk energy of which the pup stores $1315 \mathrm{MJ}$. At a typical weaning body composition this yields a pup mass gain of $56 \mathrm{~kg}$ over lactation and a weaning mass of $89 \mathrm{~kg}$. This mass is at the lower 10th percentile of the range of masses observed and will significantly 

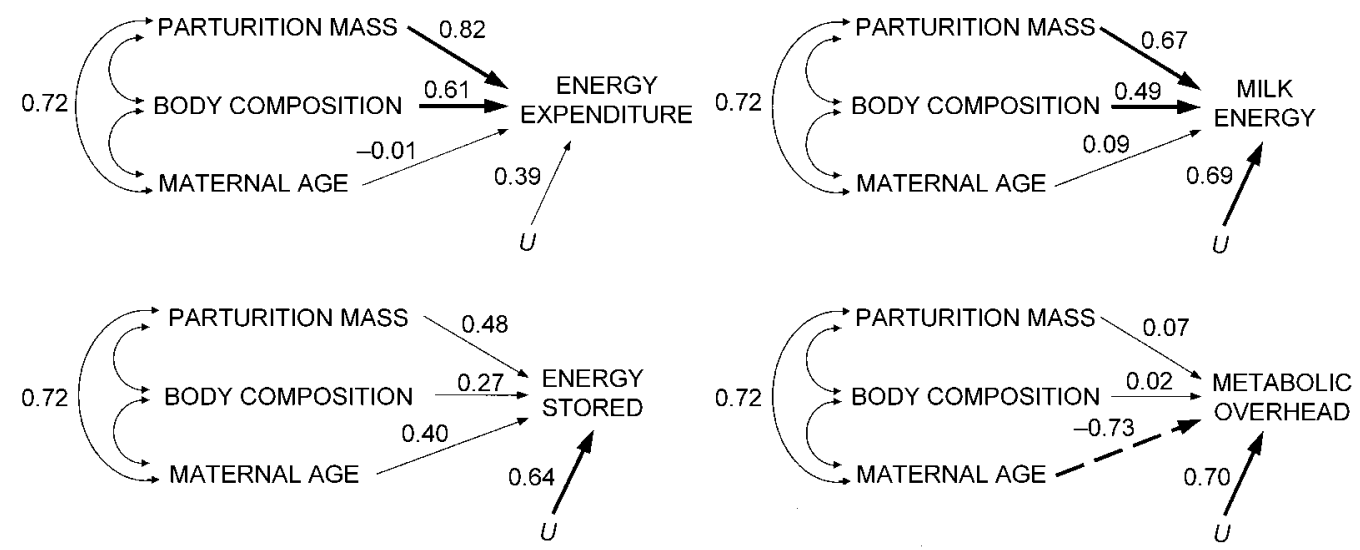

FIG. 8. Path diagram for the effects of maternal parturition mass, parturition body composition, and age on energy expenditure during lactation, milk energy delivered, energy stored by the pup over lactation, and metabolic overhead. Bidirectional arrows represent correlation coefficients. Unidirectional arrows represent path coefficients. Only significant correlations are indicated among the independent variables. Paths with significant path coefficients $(P<0.01)$ are indicated by thick lines. Positive paths are represented by solid lines, and negative paths by dashed lines. The residual variable $(U)$ represents the unmeasured factors that affect each dependent variable. For each of the path diagrams, the path coefficient for $U$ was calculated as $\left(1-R^{2}\right)^{1 / 2}$ for the $R^{2}$ of the multiple regressions.

impact the duration of the postweaning development period (Reiter et al. 1978). The point at which survival from weaning to age two appears to drop off is at a weaning mass of $80-90 \mathrm{~kg}$ (Le Boeuf et al. 1994). In very young females, the maximal maternal investment determined by physiological constraints may be close to the minimum investment required for offspring survival. There was a nonsignificant trend toward increasing proportions of total body energy expenditure in younger animals.

While costs associated with additional investment past a hypothetical body reserve threshold are likely to increase dramatically (Burley 1988), benefits should approach an asymptote. Implicit in allocation theory is the idea that increased reproductive effort, translated as increased offspring energy acquisition, carries with it fitness or survival advantages to the offspring. In elephant seals the survival advantages to the offspring of increased investment are equivocal (Le Boeuf et al. 1994). A size or energy advantage obtained very early in life might have little or no effect on reproductive success at subsequent breeding ages. Variation in the duration of the postweaning fast with weaning size (Reiter et al. 1978) or compensatory mass gain during the first trip to sea (Le Boeuf et al. 1994) might serve to mediate the effects of increased maternal investment in elephant seals. However, northern elephant seals undergo a dramatic set of developmental changes during the postweaning fast relative to the physiology necessary for deep diving (Thorson and Le Boeuf 1994). Increased fasting duration by large pups may carry developmental benefits that facilitate effective foraging in the pelagic environment. Survival to one year of age does not vary with mass at weaning; however, larger pups tend to return as larger yearlings (Le Boeuf et al. 1994). The data are insufficient to determine whether this size difference is maintained to breeding age. The wide variation in maternal investment in the present study, as well as the prevalence of potentially lethal behaviors such as milk stealing (Reiter et al. 1978), in which a pup risks all of its future reproduction to obtain a relatively small amount of additional investment, argue against a minimum level of investment above which there are no fitness advantages to the offspring.

A second possibility for the lack of age-related variation in reproductive effort is based on increased benefits to early young in a rapidly expanding population (Lewontin 1965, Charlesworth and León 1976). The selective pressure to breed early in an expanding population, as well as potential advantages in subsequent reproduction from experience (Sydeman et al. 1991), might select for increased effort in young individuals despite potential fitness costs. Calculations of reproductive value and the intrinsic rate of population increase (Reiter and Le Boeuf 1991) and estimates of annual population growth rates (Sydeman and Nur 1994) suggest that the optimal age of primiparity is four years. At the Año Nuevo rookery there is a trend toward decreasing frequencies of primiparous 3-yr-old females and an increase in females breeding for the first time at four years of age (D. Crocker, B. Le Boeuf, unpublished data). This trend has also been reported for other elephant seal rookeries (Huber et al. 1991, Sydeman et al. 1991). The impact of body reserves on allocation demonstrated in the present study may underlie fitness costs associated with early breeding and a tendency toward later primiparity as population growth declines.

A third possibility is that energetic expenditure during lactation is not an accurate index of maternal reproductive costs. Costs such as increased exposure to predation during foraging and increased susceptibility 
to disease or parasites resulting from breeding may not be reflected in energetic measures of reproductive costs. In elephant seals, potential predation costs are probably low and similar among females. Elephant seals forage in a zone that is essentially free of predators with the main risk of predation occurring in transit over the continental shelf at the beginning and end of foraging trips. Females minimize the time spent in this zone and the time at risk is independent of foraging trip duration (Le Boeuf and Crocker 1996).

Our data suggest that reproductive effort is optimized relative to individual maternal traits. Individual female effects have been described in previous studies on northern elephant seals (Sydeman and Nur 1994). These studies indicated that some females are consistently better and others are worse at successfully weaning pups. These effects accounted for more variation in mean weaning success than maternal age and breeding experience combined. These individual differences may be due to phenotypic variation or ecological variables like the initial choice of breeding site. Individual differences may similarly impact female survival and help to mask age-specific survival costs of reproduction (Partridge 1987, Nur 1988, Sydeman and Nur 1994).

Our data suggest that the tremendous efficiency with which pups stored the energy obtained from milk (84\%) is an essential component of the lactation strategy. In many mammals, the most energy expensive component of reproduction is metabolism of the nursing young (Thompson 1992). In some species these costs can be as high as $65 \%$ of maternal energy expenditure for reproduction (Nicoll and Thompson 1987). Small body size and poor insulation of many neonates can have strong impacts on maintenance energy requirements in a cold thermal environment (Hill 1983, 1992, Leon et al. 1983, Markussen et al. 1985). The large neonate body size and rapid deposition of an insulative blubber layer in elephant seals may be key components in reducing energy costs of reproduction to mothers. While we made no attempt to control for interannual variation in microclimate in the present study, the high efficiency of energy deposition in all years, despite cold and rainy winter conditions, suggests that development of thermoregulatory capacity is rapid and that maintenance costs for thermoregulation in nursing young are low. This efficiency appears to be essential in allowing young females to wean offspring with sufficient resources for survival.

Since foraging success appears to directly impact subsequent reproductive expenditure, one question raised by these results is how females respond to foraging difficulties. Elephant seals exhibit two foraging migrations separated by a molt haul-out. Elephant seals utilize embryonic diapause, with implantation thought to occur during the molt, to achieve a synchronous annual reproductive cycle. After implantation, foraging duration is likely limited by gestational progress and the necessity of terrestrial parturition. This leaves two potential options for females when ecological conditions might impact the acquisition of sufficient body reserves for successful breeding. Females can either modify the duration of the pre-implantation foraging trip or abort and delay breeding until the following year. Huber et al. (1991) suggested that skipping breeding is fairly common among multiparous females, while Le Boeuf and Reiter (1988) reported that natality varied little after first reproduction, with $97 \%$ of the females present giving birth. Investigations on foraging and reproductive parameters in El Niño years have suggested reductions in the number of parous females (Huber 1987, Le Boeuf and Reiter 1991; D. E. Crocker et al., unpublished manuscript) and dramatic increases in the duration of post-breeding foraging trip (D. E. Crocker, D. P. Costa, B. J. Le Boeuf, P. M. Webb, and D. S. Houser, unpublished manuscript). This life history pattern may serve to buffer females against short-term changes in prey availability and prevent the large-scale reproductive failures seen in other species of coastal pinnipeds and seabirds during strong ENSO events.

In conclusion, body reserves obtained during biannual foraging migrations are the most important determinants of reproductive effort in female northern elephant seals. Reproductive effort, as estimated from energy expenditure, does not vary with age, despite an increase in reproductive success and decline in the fitness costs of breeding with age evident in previous studies. Increasing maternal age does significantly impact the ability of females to translate their energy expenditure into milk production. These effects are an important consequence of the phocid strategy for enabling terrestrial parturition despite marine feeding. This strategy has resulted in an abbreviated and highly efficient lactation system that is strongly impacted by body reserves, linking foraging success at sea with reproductive success on land.

\section{ACKNOWLEDGMENTS}

We thank P. Webb, D. Houser, J. Vedder, K. Kloecker, P. Morris, P. Thorson, G. Oliver, and S. Blackwell, for assistance in the field and Clairol Corporation for providing animal marking solutions. We thank California State Parks and the Año Nuevo Rangers for logistical support. This project was funded in part by the National Science Foundation, and gifts from George Malloch and the G. MacGowan estate. Animal use was completed under NMFS permits nos. 496 and 836 . All procedures were approved by the UCSC Chancellor's Animal Research Committee. The manuscript was improved considerably by the comments of Joel Brown and two anonymous reviewers.

\section{Literature Cited}

Altmann, J. 1983. Costs of reproduction in baboons. Pages 67-77 in W. P. Aspey and S. I. Lustick, editors. Behavioral energetics: the costs of survival. Ohio State University Press, Columbus, Ohio, USA.

Bell, G. 1980. The costs of reproduction and their consequences. American Naturalist 116:45-76.

Bermann, C. M. 1988. Maternal condition and offspring sex ratio in a group of free-ranging monkeys: an eleven-year study. American Naturalist 131:307-328.

Boggs, C. L. 1992. Resource allocation: exploring connec- 
tions between foraging and life history. Functional Ecology 6:508-515.

Brody, S. 1945. Bioenergetics and growth. Haffner, New York, New York, USA.

Burley, N. 1988. The differential-allocation hypothesis: an experimental test. American Naturalist 132:611-628.

Cahill, G. F. 1978. Famine symposium: physiology of acute starvation in man. Ecological Food and Nutrition 6:221230.

Calow, P. 1979. The cost of reproduction-a physiological approach. Biological Review 54:23-40.

Charlesworth, B. 1980. Evolution in age-structured populations. Cambridge University Press, Cambridge, UK.

Charlesworth, B., and J. A. Leon. 1976. The relation of reproductive effort to age. American Naturalist 110:449-459.

Clutton-Brock, T. H. 1984. Reproductive effort and terminal investment in iteroparous animals. American Naturalist 123:212-229.

Clutton-Brock, T. H., F. E. Guiness, and S. D. Albon. 1982. Red deer: behavior and ecology of two sexes. University of Chicago Press, Chicago, Illinois, USA.

Cole, L. C. 1954. The population consequences of life history parameters. Quarterly Review of Biology 29:103-137.

Costa, D. P. 1987. Isotopic methods for quantifying material and energy intake in free-ranging marine mammals. Pages 43-66 in A. C. Huntley, D. P. Costa, G. A. J. Worthy, and M. A. Castellini, editors. Marine Mammal Energetics, Society for Marine Mammalogy Special Publication No. 1. Allen Press, Lawrence, Kansas, USA.

Costa, D. P. 1991. Reproductive and foraging energetics of pinnipeds: implications for life history patterns. Pages 300-344 in D. Renouf, editor. Pinniped behavior. Chapman Hall, New York, New York, USA.

Costa, D. P. 1993. The relationship between reproductive and foraging energetics and the evolution of the Pinnipedia. Symposium of the Zoological Society of London 66:293314.

Costa, D. P., B. J. Le Boeuf, C. L. Ortiz, and A. C. Huntley. 1986. The energetics of lactation in the northern elephant seal. Journal of Zoology, London 209:21-33.

Crocker, D. E., P. M. Webb, D. P. Costa, and B. J. Le Boeuf. 1998. Protein catabolism and renal function in lactating northern elephant seals. Physiological Zoology 71:485491.

Daan, S., C. Deerenberg, and C. Dijkstra. 1996. Increased daily work precipitates natural death in the kestrel. Journal of Animal Ecology 65:539-544.

Deutsch, C. J., D. E. Crocker, D. P. Costa, and B. J. Le Boeuf. 1994. Sex- and age-related variation in reproductive effort of northern elephant seals. Pages 169-210 in B. J. Le Boeuf and R. M. Laws, editors. Elephant seals: population ecology, behavior, and physiology. University of California Press, Berkeley, California, USA.

Deutsch, C. J., M. P. Haley, and B. J. Le Boeuf. 1990. Reproductive effort of male northern elephant seals: estimates from mass loss. Canadian Journal of Zoology 68:25802593.

Dobson, F. S. 1992. Body mass, structural size, and lifehistory patterns of the Colombian ground squirrel. American Naturalist 140:109-125.

Dobson, F. S., and G. R. Michener. 1995. Maternal traits and reproduction in Richardson's ground squirrels. Ecology 76: 851-862.

Drent, R. H., and S. Dann. 1980. The prudent parent: energetic adjustment in avian breeding. Ardea 68:225-252.

Dunham, A. E., and D. Miles. 1985. Patterns of covariation in life history traits of squamate reptiles: the effects of phylogeny and size reconsidered. American Naturalist 126: 258-260.

Fedak, M. A., and S. S. Anderson. 1982. The energetics of lactation: accurate measurements from a large wild mammal, the grey seal (Halichoerus grypus). Journal of Zoology, London 198:473-479.

Gadgil, M., and W. H. Bossert. 1970. Life historical consequences of natural selection. American Naturalist 104: $1-24$.

Gales, N. J., and H. R. Burton. 1987. Ultrasonic measurement of blubber thickness of the southern elephant seal, Mirounga leonina (Linn.). Australian Journal of Zoology 35: 207-217.

Gittleman, J. L., and S. D. Thompson. 1988. Energy allocation in mammalian reproduction. American Zoologist 28: 863-875.

Green, W. C. H., and A. Rothstein. 1991. Trade-offs between growth and reproduction in female bison. Oecologia 86: $521-527$.

Gustafsson, L., and T. Pärt. 1990. Acceleration of senescence in the collared flycatcher Ficedula albicollis by reproductive costs. Nature 347:279-281.

Hanwell, A., and M. Peaker. 1977. Physiological effects of lactation on the mother. Symposium of the Zoological Society of London 41:297-312.

Harvey, P. H. 1986. Energetic costs of reproduction. Nature 321:648-649.

Harvey, P. H., and T. Clutton-Brock. 1985. Life history variation in primates. Evolution 39:559-581.

Henneman, W. W., III . 1983. Relationship among body mass, metabolic rate and the intrinsic rate of natural increase. Oecologia 56:104-108.

Henneman, W. W., III. 1984. Intrinsic rates of natural increase of altricial and precocial eutherian mammals: the potential price of altriciality. Oikos 43:363-368.

Hill, R. W. 1983. Thermal physiology and energetics of Peromyscus: ontogeny, body temperature, metabolism, insulation, and microclimatology. Journal of Mammalogy 64 : 19-37.

Hill, R. W. 1992. The altricial/precocial contrast in the thermal relations and energetics of small mammals. Pages 122 159 in T. E. Tomasi and T. H. Horton, editors. Mammalian energetics: interdisciplinary views of metabolism and reproduction. Cornell University Press, Ithaca, New York, USA.

Horwitz, W., editor. 1975. Official methods of analysis of the association of official analytical chemists. Volume 12. McGraw-Hill, Boston, Massachusetts, USA.

Huber, H. R. 1987. Natality and weaning success in relation to age of first reproduction in northern elephant seals. Canadian Journal of Zoology 65:1311-1316.

Huber, H. R., A. C. Rovetta, L. A. Fry, and S. Johnston. 1991. Age-specific natality of northern elephant seals at the South Farralon Islands, California. Journal of Mammalogy 72: $525-534$.

Iverson, S. J., W. D. Bowen, D. J. Boness, and O. T. Oftedal. 1994. The effect of maternal size on pup growth in grey seals. Physiological Zoology 66:61-88.

Kenagy, G. J., D. Masman, S. M. Sharbaugh, and K. A. Nagy. 1990. Energy expenditure during lactation in relation to litter size in free-living golden-mantled ground squirrels. Journal of Animal Ecology 59:73-88.

Kleiber, M. 1975. The fire of life: an introduction to animal energetics. Krieger, Malabar, Florida, USA.

Kretzmann, M. B., D. P. Costa, and B. J. Le Boeuf. 1993. Maternal energy investment in elephant seal pups: evidence for sexual equality? American Naturalist 141:466-480.

Lavigne, D. M., S. Innes, G. A. J. Worthy, K. M. Kovacs, O. J. Schmitz, and J. P. Hickie. 1986. Metabolic rates of seals and whales. Canadian Journal of Zoology 64:279-284.

Le Boeuf, B. J. 1994. Variation in diving pattern of northern elephant seals with age, mass, sex, and reproductive condition. Pages 237-252 in B. J. Le Boeuf and R. M. Laws, 
editors. Elephant seals: population ecology, behavior, and physiology. University of California Press, Berkeley, California, USA.

Le Boeuf, B. J., R. Condit, and J. Reiter. 1989. Parental investment and the secondary sex ratio in northern elephant seals. Behavioral Ecology and Sociobiology 25:109-117.

Le Boeuf, B. J., and D. E. Crocker. 1996. Diving behavior of northern elephant seals: implications for predator avoidance. Pages 193-206 in A. P. Klimley and D. G. Ainley, editors. Great white sharks, the biology of Carcharodon carcharias. Academic Press, San Diego, California, USA.

Le Boeuf, B. J., P. Morris, and J. Reiter. 1994. Juvenile survivorship of northern elephant seals. Pages 121-136 in B. J. Le Boeuf and R. M. Laws, editors. Elephant seals: population ecology, behavior, and physiology. University of California Press, Berkeley, California, USA.

Le Boeuf, B. J., and J. Reiter. 1988. Lifetime reproductive success in northern elephant seals. Pages 334-362 in T. Clutton-Brock, editor. Reproductive success. University of Chicago Press, Chicago, Illinois, USA.

Lee, P. C. 1987. Nutrition, fertility, and maternal investment in primates. Journal of Zoology 213:409-422.

Lee, P. C. 1988. Ecological constraints and opportunities: interactions, relationships, and social organization of primates. Pages 297-312 in J. E. Fa and C. H. Southwick, editors. Ecology and behavior of food-enhanced primate groups. A. R. Liss, New York, New York, USA.

Lee, P. C., and C. J. Moss. 1986. Early maternal investment in male and female African elephant calves. Behavioral Ecology and Sociobiology 18:353-361.

Leon, M., C. Fischette, P. Chee, and B. Woodside. 1983. Energetic limits on reproduction: interaction of thermal and dietary factors. Physiological Behavior 30:945-957.

Lewontin, R. C. 1965. Selection for colonizing ability. Pages 77-91 in H. G. Baker and G. L. Stebbins, editors. The genetics of colonizing species. Academic Press, New York, New York, USA.

Li, C. C. 1981. Path analysis-a primer. Boxwood, Pacific Grove, California, USA.

Linzell, J. L. 1972. Milk yield, energy loss in milk, and mammary gland weight in different species. Dairy Science Abstracts 34:351-360.

Loudon, A. S. I., and P. A. Racey, editors. 1987. Reproductive energetics in mammals. Symposium of the Zoological Society of London 57. Clarendon Press, Oxford, UK.

Lucas, A., G. Ewing, S. B. Roberts, and W. A. Coward. 1987. How much energy does the breast fed infant consume and expend? British Medical Journal 295:75-77.

Markussen, K. A., A. Rognomo, and A. S. Blix. 1985. Some aspects of thermoregulation in newborn reindeer calves (Rangifer tarandus tarandus). Acta Physiologica Scandinavia 123:215-220.

Martin, R. D. 1984a. Body size, brain size, and feeding strategies. Pages 73-103 in D. J. Chivers, B. A. Wood, and A. Bilsborough, editors. Food acquisition and processing in primates. Plenum, New York, New York, USA.

Martin, R. D. 1984b. Scaling effects and adaptive strategies. Symposium of the Zoological Society of London 51:87117.

Martin, T. E. 1987. Food as a limit on breeding birds: a lifehistory perspective. Annual Review of Ecology and Systematics 18:453-487.

McNab, B. K. 1980. Food habits, energetics, and the population biology of mammals. American Naturalist 116:106124.

Mitchell, R. J. 1992. Testing evolutionary and ecological hypotheses using path analysis and structural equation modeling. Functional Ecology 6:123-129.

Nagy, K. A. 1980. $\mathrm{CO}_{2}$ production in animals: analysis of potential errors in the doubly labeled water method. American Journal of Physiology 238:R466-R473.

Nagy, K. A., and D. P. Costa. 1980. Water flux in animals: an analysis of potential errors in the tritiated water method. American Journal of Physiology 238:R454-R465.

Nicoll, M. E., and S. D. Thompson. 1987. Basal metabolic rates and energetics of reproduction in therian mammals: marsupials and placentals compared. Symposium of the Zoological Society of London 57:1-27.

Nur, N. 1988. The cost of reproduction in birds: an examination of the evidence. Ardea 76:155-168.

Oftedal, O. T., and J. L. Gittleman. 1988. Patterns of energy output during reproduction in carnivores. Pages 355-377 in J. L. Gittleman, editor. Carnivore behavior and biology. Cornell University Press, Ithaca, New York, USA.

Oftedal, O. T., and S. J. Iverson. 1987. Hydrogen isotope methodology for measurement of milk intake and energetics of growth in suckling young. Pages 67-96 in A. C. Huntley, D. P. Costa, G. A. J. Worthy, and M. A. Castellini, editors. Marine Mammal Energetics, Society for Marine Mammalogy Special Publication No. 1. Allen Press, Lawrence, Kansas, USA.

Oliveras, D., and M. Novak. 1986. A comparison of paternal behavior in the meadow vole Microtus pennsylvanicus, the pine vole $M$. pinetorum and the praire vole $M$. ocrogaster. Animal Behavior 34:519-526.

Ortiz, C. L., B. J. Le Boeuf, and D. P. Costa. 1984. Milk intake of elephant seal pups: an index of parental investment. American Naturalist 124:416-422.

Partridge, L. 1987. Is accelerated senescence a cost of reproduction? Functional Ecology 1:317-320.

Patton, J. L., and P. V. Brylski. 1987. Pocket gophers in alfalfa fields: causes and consequences of habitat-related body size variation. American Naturalist 130:493-506.

Peaker, M., R. G. Vernon, and C. H. Knight. 1984. Physiological strategies in lactation. Academic Press, London, UK.

Pedhazur, E. J. 1982. Multiple regression in behavioral research. Holt, Rhinehart and Winston, New York, New York, USA.

Pianka, E. R., and W. S. Parker. 1975. Age-specific reproductive tactics. American Naturalist 109:453-464.

Reilly, J. J., and M. A. Fedak. 1991. Rates of water turnover and energy expenditure of free-living male common seals (Phoca vitulina). Journal of Zoology, London 223:461468.

Reiter, J., and B. J. Le Boeuf. 1991. Life history consequences of variation in age of primaparity in northern elephant seals. Behavioral Ecology and Sociobiology 28: $153-160$.

Reiter, J., K. J. Panken, and B. J. Le Boeuf. 1981. Female competition and reproductive success in northern elephant seals. Animal Behavior 29:670-687.

Reiter, J., N. L. Stinson, and B. J. Le Boeuf. 1978. Northern elephant seal development: the transition from weaning to nutritional independence. Behavioral Ecology and Sociobiology 3:337-367.

Riedman, M., and C. L. Ortiz. 1979. Changes in milk composition during lactation in the northern elephant seal. Physiological Zoology 52:240-249.

SAS Institute. 1990. SAS. SAS Institute, Cary, North Carolina, USA.

Schaffer, W. M. 1974. Selection for optimal life histories: the effects of age structure. Ecology 5:291-303.

Schemske, D. W., and C. C. Horvitz. 1988. Plant-animal interactions and fruit production in a neotropical herb: a path analysis. Ecology 69:1128-1137.

Schmidt-Nielsen, K. 1975. Animal physiology: adaptation and environment. Second edition. Cambridge University Press, Cambridge, UK. 
Stearns, S. C. 1976. Life history tactics: a review of the ideas. Quarterly Review of Biology 51:3-47.

Stearns, S. C. 1992. The evolution of life histories. Oxford University Press, Oxford, UK.

Stearns, S. C. 1983. The influence of size and phylogeny on patterns of covariation among life-history traits of lizards and snakes. Oikos 41:173-87.

Stewart, B. S., P. K. Yochem, H. R. Huber, R. L. DeLong, R. J. Jameson, W. J. Sydeman, S. G. Allen, and B. J. Le Boeuf. 1994. History and present status of the northern elephant seal population. Pages 29-48 in B. J. Le Boeuf and R. M. Laws, editors. Elephant seals: population ecology, behavior, and physiology. University of California Press, Berkeley, California, USA.

Sydeman, W. J., H. R. Huber, S. D. Emslie, C. A. Ribic, and N. Nur. 1991. Age-specific weaning success of northern elephant seals in relation to previous breeding experience. Ecology 72:2204-2217.

Sydeman, W. J., and N. Nur. 1994. Life history strategies of female northern elephant seals. Pages 121-136 in B. J. Le Boeuf and R. M. Laws, editors. Elephant seals: population ecology, behavior, and physiology. University of California Press, Berkeley, California, USA.

Thompson, S. D. 1992. Gestation and lactation in small mammals: basal metabolic rate and the limits of energy use. Pages 213-259 in T. E. Tomasi and T. H. Horton, editors. Mammalian energetics: interdisciplinary views of metabolism and reproduction. Cornell University Press, Ithaca, New York, USA.

Thorson, P. H., and B. J. Le Boeuf. 1994. Developmental aspects of diving in northern elephant seal pups. Pages 271289 in B. J. Le Boeuf and R. M. Laws, editors. Elephant seals: population ecology, behavior, and physiology. University of California Press, Berkeley, California, USA.

Trillmich, F. 1986. Maternal investment and sex allocation in the Galapagos fur seal, Arctocephalus galapagoensis. Behavioral Ecology and Sociobiology 19:157-164.

Tuomi, J., T. Hakala, and E. Haukioja. 1983. Alternative concepts of reproductive effort, costs of reproduction, and selection in life-history evolution. American Zoologist 23: 25-34.

Tyler, N. J. C. 1987. Body composition and energy balance of pregnant and non-pregnant Svalbard reindeer during winter. Symposium of the Zoological Society of London 57:203-229.

Van Noordwijk, A. J., and G. de Jong. 1986. Acquisition and allocation of resources: their influence on variation in life history tactics. American Naturalist 128:137-142.

Vaughan, B. E., and E. A. Boling. 1961. Rapid assay procedures for tritium-labeled water in body fluids. Journal of Laboratory Clinical Medicine 57:159.

Webb, P. M., D. E. Crocker, S. B. Blackwell, D. P. Costa, and B. J. Le Boeuf. 1998. The effects of buoyancy on the diving behavior of northern elephant seals. Journal of Experimental Biology 201:2349-2358.

Weimerskirch, H., Y. Cherel, F. Cuenot-Chaillet, and V. Ridoux. 1997. Alternative foraging strategies and resource allocation by male and female wandering albatrosses. Ecology 78:2051-2063.

Western, D. 1979. Size, life history and ecology in mammals. African Journal of Ecology 17:185-204.

Western, D., and J. Ssemakula. 1982. Life history patterns in birds and mammals and their evolutionary interpretation. Oecologia 54:281-290.

Williams, G. C. 1966. Natural selection, the cost of reproduction, and a refinement of Lack's principle. American Naturalist 100:687-690.

Worthy, G. A. J., P. A. Morris, D. P. Costa, and B. J. Le Boeuf. 1992. Moult energetics of the northern elephant seal. Journal of Zoology, London 227:257-265. 